\title{
Passport data and valorisation data of 33 accessions from the collection of genetic resources of the species Linum usitatissimum L.
}

\author{
GRAŻYNA SILSKA®
}

Institute of Natural Fibres and Medicinal Plants

Wojska Polskiego 71B

60-630 Poznań, Poland

Address for correspondence: phone +48 61 8455838; email: grazyna.silska@iwnirz.pl

\section{Summary}

Introduction: In 2020, the Institute of Natural Fibres and Medicinal Plants (INF\&MP) implemented the contract No. 7/PW 1.2 - IWNiRZ Poznan'/KCRZG/2020 for the performance of a research service under the long-term programme "Creating scientific foundations for biological progress and protection of plant genetic resources as a source of innovation and support for sustainable agriculture and safety food for country".

Objective: The aim of the research was to prepare passport and valorisation data for 33 accessions of flax (Linum usitatissimum L.) sown at the INF\&MP Experimental Station in Pętkowo.

Methods: The field experiment was conducted on 33 samples of flax seeds, which were sown on an area of $1.6 \mathrm{~m}^{2}$. Morphological features were presented by means of numerical data and their evaluation. The agricultural characteristics (numerical values and percentage of the collective pattern) and lengths of vegetation period were also presented. The evaluation of the performed characteristics of flax accessions was presented numerically and the data were given to the International Flax Database.

Results: On the basis of paper documentation, the country of origin of the accessions, the type of genotypes by origin (landrace, variety) and the date of inclusion of the accessions in the flax collection were determined. The results of the characterization of morphological trials were as follows: the total plant length of the flax plants ranged from $51.4 \mathrm{~cm}$ (La Estanzuella 117) to $76.5 \mathrm{~cm}$ (WUKR 06-417) According to the methodology of the International Flax Database, the total plant length were short (28 accessions), medium short (3) and medium (1). Technical length was usually short (28 accessions) and medium short (4 accessions). Stem thickness for all accessions was medium: $1.6-2.5 \mathrm{~mm}$. The length of the panicle was long only for the Opal variety, for 25 accessions - medium and short for 6 accessions. A number of bolls from panicle was: 9.1-30.8. The 1000 seed weight was low for 25 accessions of flax and very low for 8 genotypes of flax.

Conclusions: Both studied vegetation periods were short in the following flax accessions: AC Linora, Manchwrian, Noralta and T-397. Flax genotype WUKR-846 (I2010/0031) should be deleted from the flax genetic resources collection and considered as worthless as breeding material. The WUKR 06-417 accession collected during the field expedition is distinguished by a high fibre content $-27 \%$. The highest seed yield 
per plot was obtained from the cultivation of the following linseed flax cultivars: Redwood, AC Mc Duff, Norlin, Noralta and Jenny.

Key words: genetic resources, flax, Linum usitatissimum L., morphological traits, biological features, agricultural traits

Słowa kluczowe: zasoby genetyczne, len, Linum usitatissimum L., cechy morfologiczne, cechy biologiczne, cechy rolnicze

\section{INTRODUCTION}

Currently, we are witnessing a large loss of biodiversity in agriculture. Fewer crop species are cultivated in the $21^{\text {st }}$ century than in the $20^{\text {th }}$ century. An important criterion in selecting species for cultivation is obtaining the greatest possible income. The loss of biodiversity necessitates the preservation of valuable plant species in seed banks. The seed bank of cultivated plants, in which genetic resources are stored for a long time, is located in the Plant Breeding and Acclimatization Institute (IHAR), Poland. The genotypes of crops stored there are characterized by many important morphological, biological or agricultural features that can be used by breeders to work on new varieties. Therefore, it is very important to know the passport data and valorisation data of flax accessions. Flax is a species of particular importance for human health, and its benefits have been appreciated for decades. In the $20^{\text {th }}$ century, flax seed was popular both in the kitchen and in the field. Preserving the genetic resources of flax (Linum usitatissimum L.) is of great importance for society, because this plant is very important in the prevention of civilization diseases (cardiovascular, cancer, mental diseases and many others), in many branches of the economy and in environmental protection nature and climate. The importance of flax in medicine is primarily due to the extremely beneficial composition of the seeds: $\alpha$-linolenic acid, valuable amino acids and fiber, many anti-aging antioxidants [1-4].

In the economy, flax is used in products characterized by valuable health properties and biodegradable. The flax species should be appreciated as having enormous health and ecological potential, because health problems, loss of biodiversity, problems with environmental pollution and climate warming are the biggest problems in the world.

\section{MATERAL AND METHODS}

The passport data of flax accessions sown in 2010 in Pętkowo on $1.6 \mathrm{~m}^{2}$ plots are presented in table 1 . Most of studied flax accessions - 27, (Institution code) were collected by the Institute of Natural Fibres, now Institute of Natural Fibres and Medicinal Plant (INF\&MP). Five genotypes of flax were included in the collection of genetic resources of the Linum usitatissimum L. species by the Plant Breeding and Acclimatization Institute (IHAR) during field expedition. One cultivar from Breeding Strzelce also participated in the experiment. The flax accessions were collected from 1984 (Manchwrian, Noralta, Redwood) to 2010 (WUKR 06-268, WUKR-723, WUKR 06-417, WUKR-846, WIG 0914) (acquisition date). The largest number of flax genotypes comes from Poland (6 accessions); Czech Republic, Canada, Denmark, Great Britain (3 accessions of flax); Argentina, Uruguay, Germany (2 genotypes) and India, USA, France, Morocco, Sweden (1 flax accession) (fig. 1). The tested genotypes are 25 varieties of flax and 8 breeding lines (origin).

The summary of meteorological data for the growing season in 2010 in Experimental Station in Pętkowo are showed in table 2 and the morphological characteristics and valorisation of 33 accessions of flax are showed in table 3 . The collected accessions are stored as seeds in the National Centre for Plant Genetic Resources at the IHAR in Radzików near Warsaw [5]. The valorisation of 33 accessions of flax was carried out using the traditional method and the method used in the development of the International Flax $\mathrm{Da}$ tabase (IFDB), using the descriptor states [6-8].

In the paper of J. Nôžková we can find ranges of numerical values for individual morphological, biological and agricultural features. At INF\&MP, we introduce the new methods of characterisation of flax genotypes. Morphological features are presented as numerical values and a specific evaluation of 5 features (tab. 3). Each tested accession was classified into one of the following groups: very short, short, medium, long, very long [8]. In 2010 growing season in Pętkowo phenological phases were observed, on the basis of which two vegetation period were determined presented in table 4 (biological features): vegetation period from sowing to beginning of flowering, and vegetation period from sowing to yellow maturity. 


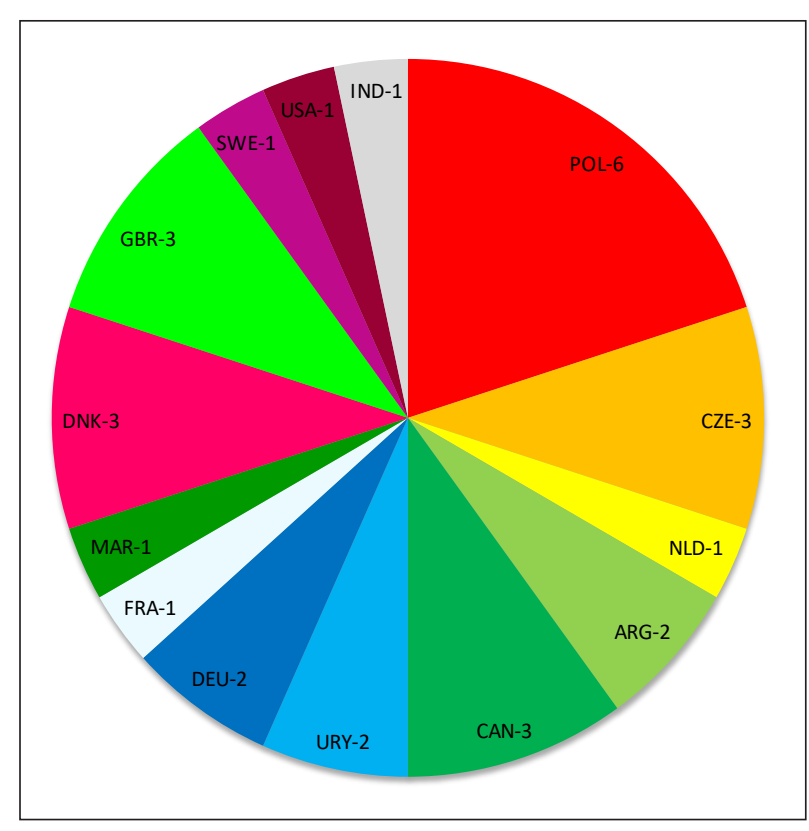

Figure 1.

Characteristics of accessions of flax (Linum usitatissimum L.) according to the country of origin

legend: POL - Poland; CZE - Czech Rep.; NDL Netherlands; ARG - Argentina; CAN - Canada; URY - Uruguay; DEU - Germany; FRA - France; MAR - Morocco; DNK - Denmark; GBR - Great Britain; SWE - Sweden; USA - United States of America; IND - India

Each tested accession was classified into one of the following groups: very short, short, medium, long, very long [8]. The agricultural characteristics consisted of determining the following features: fibre content in straw, total yield, yield of straw and seed yield (tab. 5).
The following states of descriptors, according to J. Nozkova for 7 morphological traits, listed below, were used [8]:

1. Total plant length short: $310-649 \mathrm{~mm}$ medium short: $650-769 \mathrm{~mm}$ medium: $700-879 \mathrm{~mm}$

2. Technical length short: $250-549 \mathrm{~mm}$ medium short: $550-649 \mathrm{~mm}$ medium: $650-749 \mathrm{~mm}$

3. Stem thickness thin: $<1.2 \mathrm{~mm}$ medium: $1.2-2.0 \mathrm{~mm}$ thick: $>2.0 \mathrm{~mm}$

4. Panicle-like size short: $7-21 \%$ of plant natural height medium: $22-34 \%$ of plant natural height long: $35-48 \%$ of plant natural height

5. 1000 seed weight very low: $<4.50 \mathrm{~g}$ low: $4.5-7.49 \mathrm{~g}$ medium: $7.50-10.49 \mathrm{~g}$

The results were calculated as average of 20 plants. In our examination it was not possible to evaluate the economic traits for International Flax Database, because in this methodology seed plots should have $10 \mathrm{~m}^{2}$. The work presents the data from experimental plots with an area of $1.6 \mathrm{~m}^{2}$. The value of the collective pattern (mean of all tested accessions) was calculated for all agricultural traits. For each accessions of flax, the percentage of the collective pattern was calculated (tab. 5).

Ethical approval: The conducted research is not related to either human or animal use.

Table 1.

The passport data of 33 accessions of flax (Linum usitatissimum L.)

\begin{tabular}{|c|c|c|c|c|c|c|c|c|c|c|}
\hline 1. & 2. & 3. & 4. & 5. & 6. & 7. & 8. & 9. & 10. & 11. \\
\hline INF01010 & WUKR 06-268 & POL003 & 2010 & POL & 4 & Linum & $\begin{array}{c}\text { usitatissi- } \\
\text { mum }\end{array}$ & POL003 & fibre & I2010/0028 \\
\hline INF01011 & WUKR-723 & POL003 & 2010 & POL & 4 & ” & $”$ & POL003 & linseed & I2010/0029 \\
\hline INF01012 & WUKR 06-417 & POL003 & 2010 & POL & 4 & $”$ & $”$ & POL003 & fibre & I2010/0030 \\
\hline INF01013 & WUKR-846 & POL003 & 2010 & CZE & 4 & ” & $”$ & POL003 & linseed & I2010/0031 \\
\hline INF01014 & WIG 09-14 & POL003 & 2010 & GRB & 4 & $”$ & $”$ & POL003 & linseed & I2010/0038 \\
\hline INF00685 & Abby & POL026 & 1998-02-17 & CZE & 3 & ” & $”$ & POL003 & linseed & 165786 \\
\hline- & AC Linora & POL026 & & - & 3 & $”$ & ” & POL003 & linseed & - \\
\hline INF00648 & AC Mc Duff & POL026 & 1999 & NLD & 3 & ” & $”$ & POL003 & linseed & 166155 \\
\hline INF00683 & Alfonso Inta & POL026 & 1999 & ARG & 3 & ” & ” & POL003 & linseed & 166177 \\
\hline- & Amon & POL026 & 2000 & CZE & 3 & $”$ & $”$ & POL003 & linseed & - \\
\hline
\end{tabular}


Table 2. (continued)

\begin{tabular}{|c|c|c|c|c|c|c|c|c|c|c|}
\hline 1. & 2. & 3. & 4. & 5. & 6. & 7. & 8. & 9. & 10. & 11. \\
\hline INF00540 & Duffern & POL026 & 1999 & CAN & 3 & $”$ & $”$ & POL003 & linseed & $\begin{array}{l}166070 \\
166113\end{array}$ \\
\hline INF00592 & Jenny & POL026 & 1999 & POL & 4 & $”$ & $"$ & POL003 & linseed & 166089 \\
\hline INF00061 & Kotowicki & POL026 & & POL & 3 & $”$ & $”$ & POL003 & linseed & 165574 \\
\hline INF00692 & Kreola & POL026 & 1998 & GER & 3 & $”$ & $"$ & POL003 & linseed & 166185 \\
\hline- & La Estanzuela 17 & POL026 & & URY & 4 & $”$ & $”$ & POL003 & linseed & - \\
\hline INF00575 & La Estanzuela 117 & POL026 & 1991 & URY & 4 & $”$ & $”$ & POL003 & linseed & 166073 \\
\hline INF00578 & La Prevision & POL026 & 1999 & ARG & 3 & $”$ & $”$ & POL003 & linseed & 16676 \\
\hline INF00065 & LCSD 200 & POL026 & & - & 3 & $”$ & ” & POL003 & linseed & \\
\hline INF00580 & Lino de Pedre & POL026 & 1991 & DEU & 3 & $”$ & $"$ & POL003 & linseed & 166078 \\
\hline INF00843 & Lola & POL026 & & CAN & 3 & $”$ & ” & POL003 & linseed & 166270 \\
\hline- & Manchwrian & POL026 & 1984 & FRA & 3 & $”$ & $"$ & POL003 & - & 165583 \\
\hline INF00273 & Medra & POL026 & 1987 & DEU & 3 & $”$ & $"$ & POL003 & linseed & 165787 \\
\hline INF00584 & Maroc & POL026 & 1999 & MAR & 3 & $”$ & $”$ & POL003 & linseed & 165787 \\
\hline $\begin{array}{l}\text { INF00080 } \\
\text { INF00617 }\end{array}$ & Noralta & POL026 & 1984 & CAN & 3 & $”$ & $”$ & POL003 & linseed & $\begin{array}{l}165591 \\
166111 \\
\end{array}$ \\
\hline INF00547 & Norlin & POL026 & 1999 & & 3 & $”$ & $”$ & POL003 & linseed & 166106 \\
\hline INF00687 & Olinette & POL026 & 1998-02-18 & DNK & 3 & $”$ & $”$ & POL003 & linseed & 166180 \\
\hline INF00635 & Opal & POL054 & 1994-02-28 & POL & 3 & $”$ & $"$ & POL003 & linseed & 166125 \\
\hline INF00686 & Peak & POL026 & 1998-02-17 & GBR & 3 & $”$ & $”$ & POL003 & linseed & 166179 \\
\hline INF00290 & Rau & POL026 & 1987 & SWE & 3 & $"$ & $"$ & POL003 & linseed & 165808 \\
\hline INF00096 & Redwood & POL026 & 1984 & USA & 3 & $”$ & $”$ & POL003 & linseed & 165552 \\
\hline INF00689 & Royale & POL026 & 1998-02-18 & DNK & 3 & $”$ & $"$ & POL003 & linseed & 166182 \\
\hline INF00604 & T-397 & POL026 & 2005 & - & 3 & $”$ & $”$ & POL003 & - & 166212 \\
\hline INF00602 & Tawahar 17 & POL026 & 2006 & IND & 3 & $"$ & ” & POL003 & - & 16282 \\
\hline
\end{tabular}

1. Accession number; 2. Accession name; 3. Institution code POL003-PBXAI, POL026-INF, POL054-Strzelce; 4. Acquisition date time of including accession into collection of flax; 5. Country of origin; 6. Origin (type of accession based on its origin): $4-$ landrace, 3 - variety; 7. Genus: Linum; 8. Species: Linum usitatissimum L.; 9. Institute code; 10. Type of use; 11. Collecting number (number of National Centre for Plant Genetic Resources - IHAR Radzików)

Table 2.

Summary of meteorological data for the growing season in 2010 - Experimental Station in Pętkowo

\begin{tabular}{|c|c|c|c|c|c|c|c|c|c|c|c|c|c|c|c|c|c|c|}
\hline \multirow{3}{*}{ Decade } & \multicolumn{6}{|c|}{ Rainfall [mm] } & \multicolumn{12}{|c|}{ Temperature $\left[{ }^{\circ} \mathrm{C}\right]$} \\
\hline & \multirow[b]{2}{*}{ III } & \multirow[b]{2}{*}{ IV } & \multirow[b]{2}{*}{$\mathrm{V}$} & \multirow[b]{2}{*}{ VI } & \multirow[b]{2}{*}{ VII } & \multirow[b]{2}{*}{ VIII } & \multicolumn{2}{|c|}{ III } & \multicolumn{2}{|c|}{ IV } & \multicolumn{2}{|c|}{$\mathrm{V}$} & \multicolumn{2}{|c|}{ VI } & \multicolumn{2}{|c|}{ VII } & \multicolumn{2}{|c|}{ VIII } \\
\hline & & & & & & & $\begin{array}{l}\text { Aver- } \\
\text { age }\end{array}$ & Min. & $\begin{array}{l}\text { Aver- } \\
\text { age }\end{array}$ & Min. & $\begin{array}{l}\text { Aver- } \\
\text { age }\end{array}$ & Min. & $\begin{array}{c}\text { Aver- } \\
\text { age }\end{array}$ & Min. & $\begin{array}{l}\text { Aver- } \\
\text { age }\end{array}$ & Min. & $\begin{array}{l}\text { Aver- } \\
\text { age }\end{array}$ & Min. \\
\hline I & 1.1 & 18.5 & 17.0 & 8.6 & 18.5 & 27.8 & -1.9 & -5.4 & 7.0 & 2.6 & 11.0 & 7.3 & 18.0 & 12.1 & 21.6 & 14.8 & 19.6 & 14.8 \\
\hline II & 11.4 & 3.0 & 65.0 & 17.0 & 2.5 & 36.6 & 2.7 & -0.7 & 8.8 & 3.5 & 10.8 & 8.2 & 16.2 & 9.5 & 24.4 & 17.4 & 19.5 & 15.2 \\
\hline III & 23.0 & 9.5 & 14.0 & 0.0 & 75.0 & 56.0 & 8.6 & 4.3 & 10.1 & 3.9 & 13.8 & 9.2 & 17.8 & 9.5 & 20.3 & 15.4 & 16.8 & 13.0 \\
\hline $\begin{array}{l}\text { Total rainfall } \\
{[\mathrm{mm}]}\end{array}$ & 35.5 & 31.0 & 96.0 & 25.6 & 96.0 & 120.4 & - & - & - & - & - & - & - & - & - & - & - & - \\
\hline $\begin{array}{l}\text { Average month } \\
\text { temperatures } \\
{\left[{ }^{\circ} \mathrm{C}\right]} \\
\end{array}$ & - & - & - & - & - & - & 3.3 & - & 8.6 & - & 11.9 & - & 17.4 & - & 22.0 & - & 18.6 & - \\
\hline $\begin{array}{l}\text { Long-term } \\
\text { average }\end{array}$ & 33.0 & 29.0 & 41.1 & 41.7 & 66.7 & 59.0 & 3.2 & - & 9.1 & - & 14.3 & - & 17.5 & - & 19.5 & - & 18.9 & - \\
\hline
\end{tabular}

Note: rainfall in III and VIII and temperature in III-VIII - data from Experimental Station in Słupia Wielka; long-term period 1996-2018 


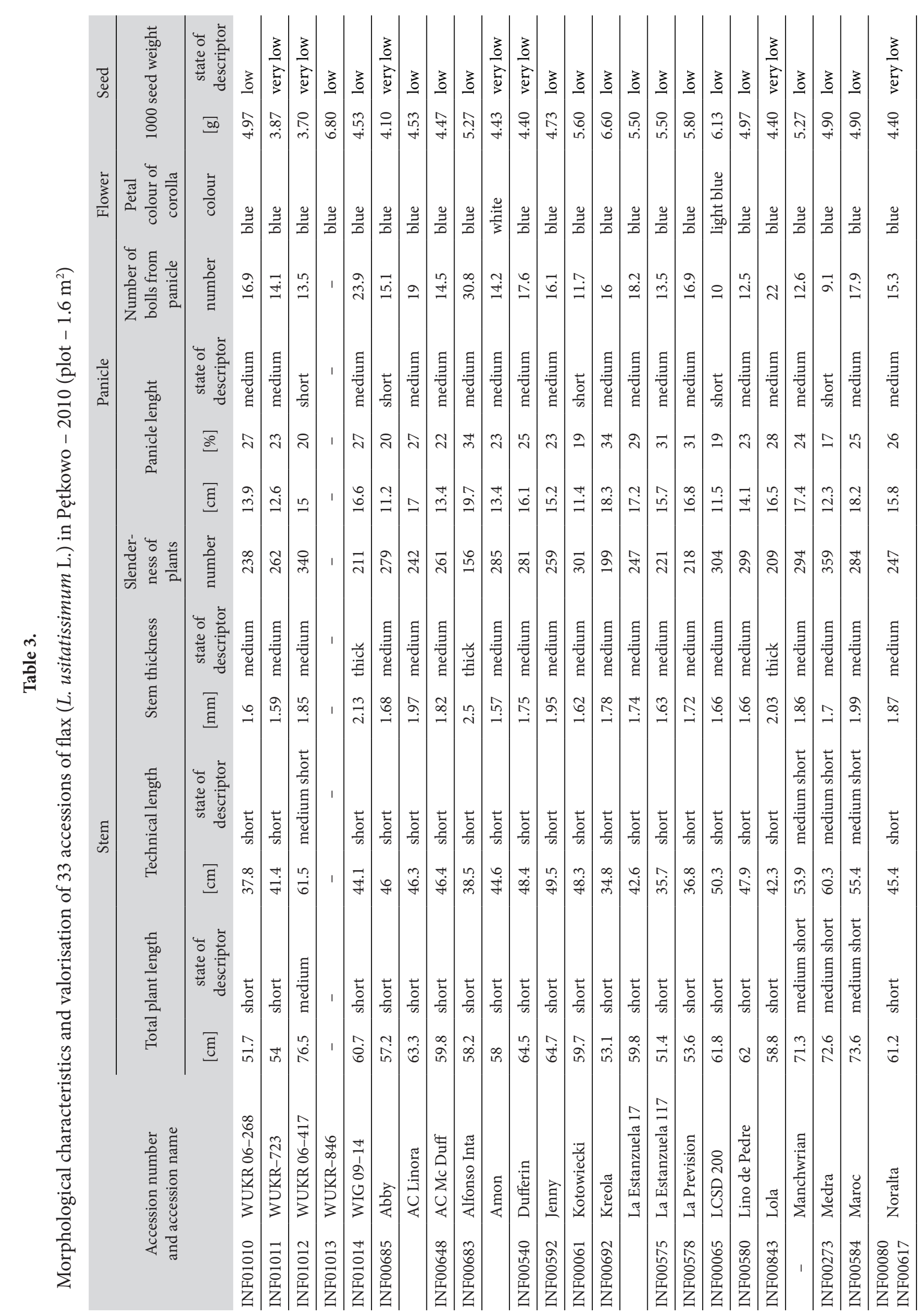




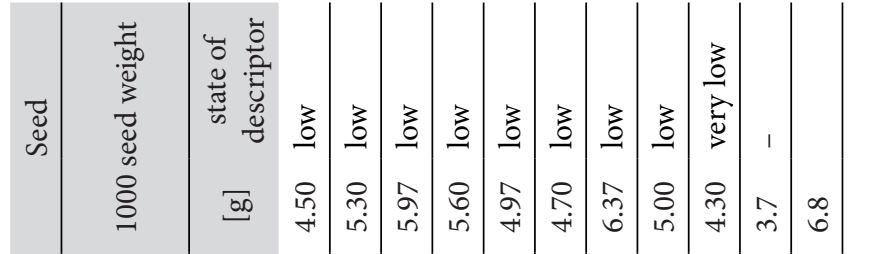

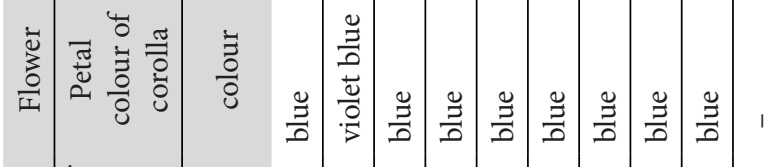

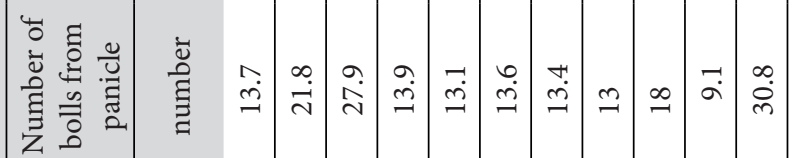

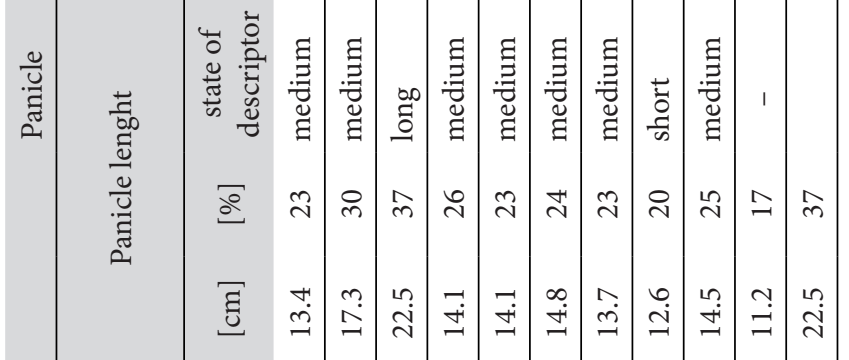

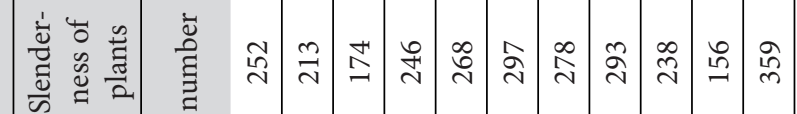

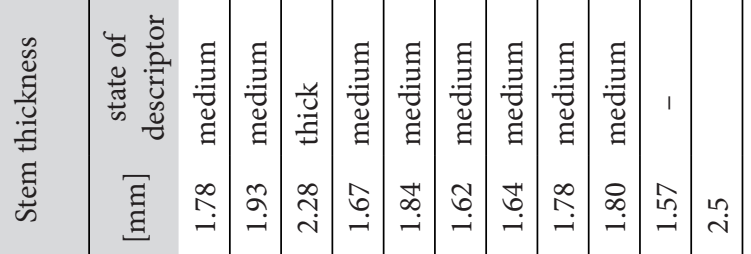

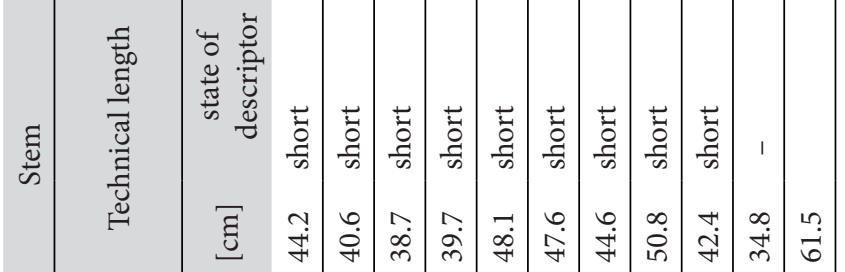

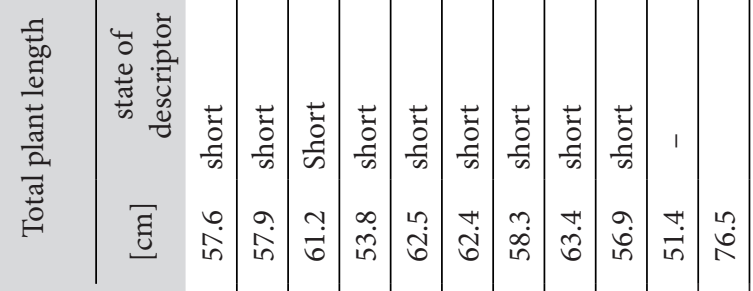

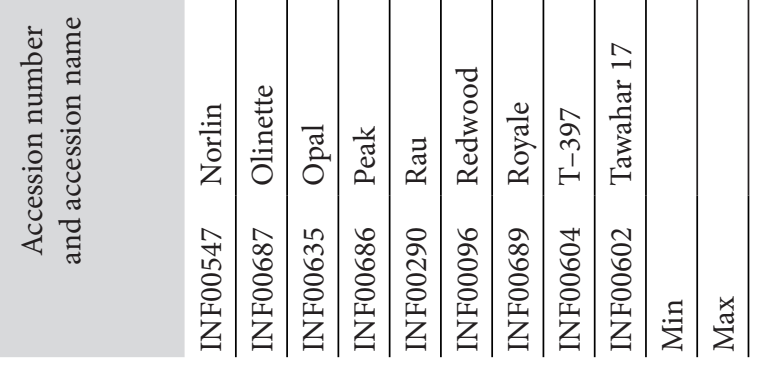

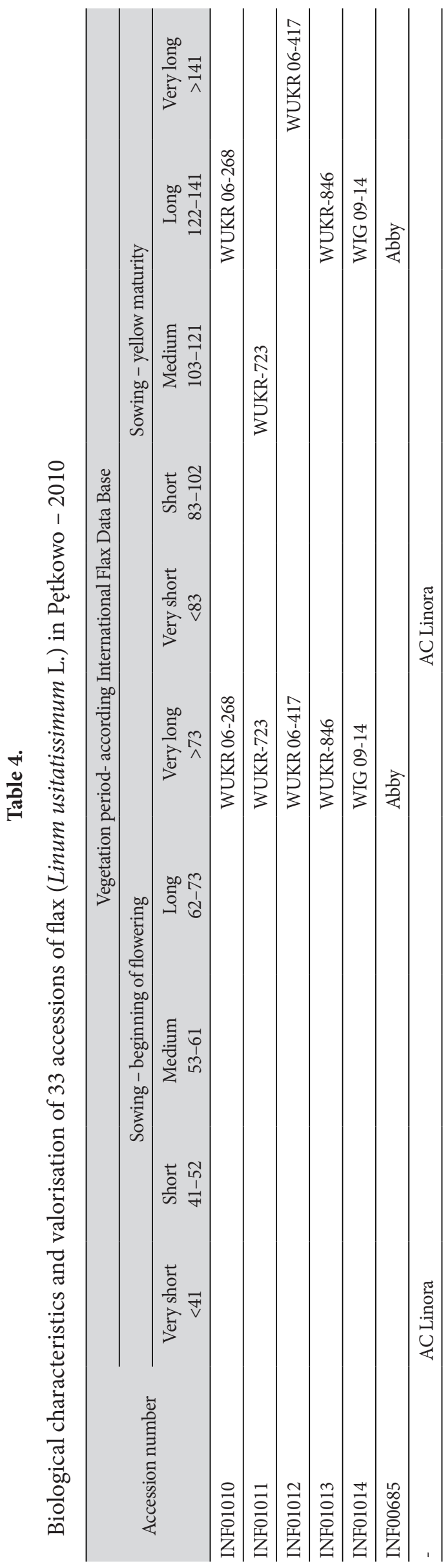




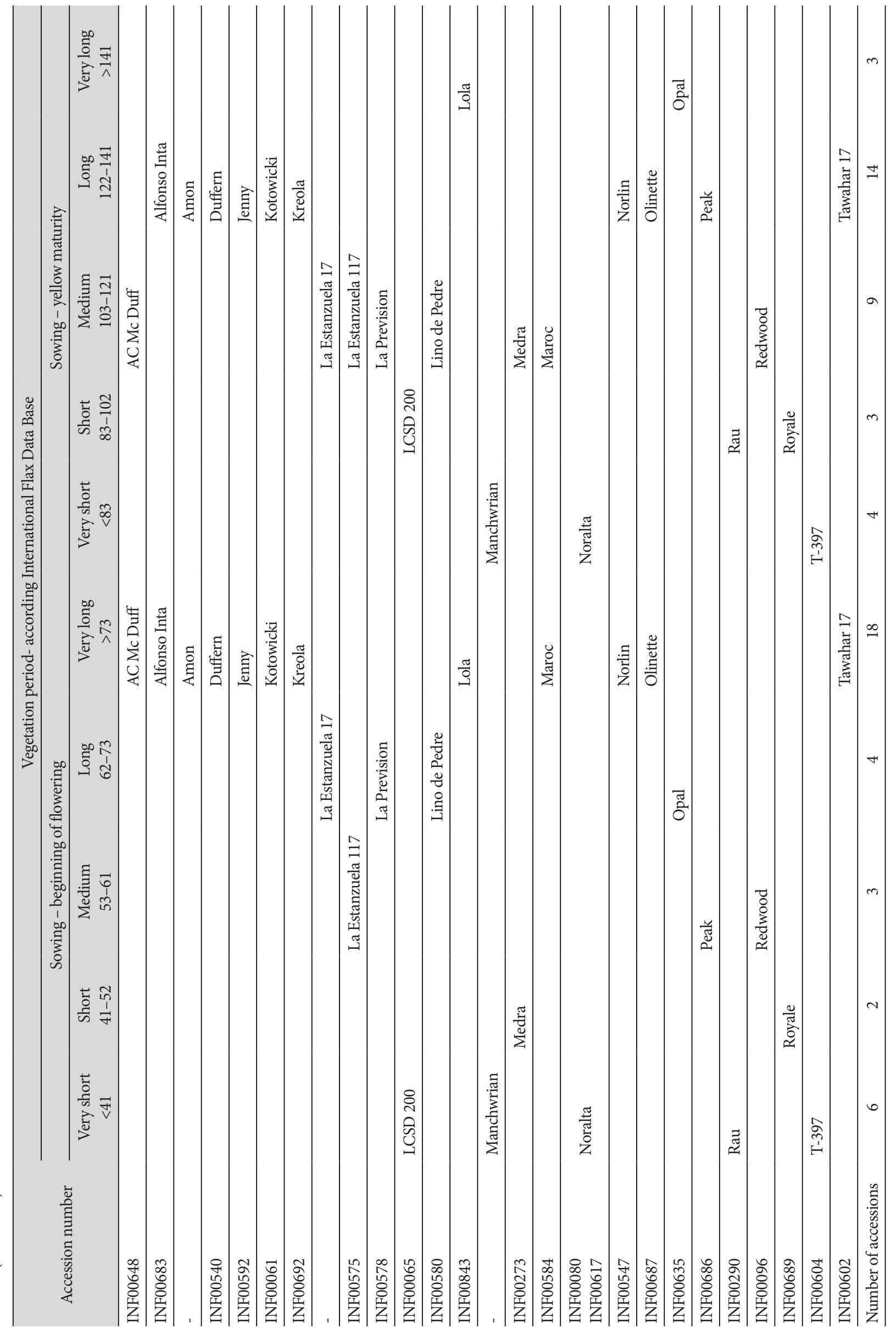


Table 5.

Agricultural valorisation of 33 accessions of flax (Linum usitatissimum L.) in Pętkowo - 2010

\begin{tabular}{|c|c|c|c|c|c|c|c|c|c|}
\hline \multirow[b]{2}{*}{$\begin{array}{c}\text { Accession } \\
\text { number }\end{array}$} & \multirow[b]{2}{*}{ Accession name } & \multicolumn{2}{|c|}{ Fibre content in stem } & \multicolumn{2}{|c|}{ Total yield } & \multicolumn{2}{|c|}{ Yield of straw } & \multicolumn{2}{|c|}{ Seed yield } \\
\hline & & [\%] & $\begin{array}{l}\text { the percentage } \\
\text { of the collec- } \\
\text { tive pattern } \\
\text { (14.3) }\end{array}$ & $\begin{array}{l}{[\mathrm{kg} /} \\
\text { plot }]\end{array}$ & $\begin{array}{c}\text { the percentage } \\
\text { of the collec- } \\
\text { tive pattern } \\
(0.87)\end{array}$ & $\begin{array}{l}{[\mathrm{kg} /} \\
\text { plot }]\end{array}$ & $\begin{array}{l}\text { the percentage } \\
\text { of the collec- } \\
\text { tive pattern } \\
(0.50)\end{array}$ & $\begin{array}{l}{[\mathrm{kg} /} \\
\text { plot }]\end{array}$ & $\begin{array}{l}\text { the percentage } \\
\text { of the collec- } \\
\text { tive pattern } \\
(0.18)\end{array}$ \\
\hline INF 01010 & WUKR 06-268 & 15.6 & 109 & 0.826 & 95 & 0.241 & 48 & 0.122 & 68 \\
\hline INF 01011 & WUKR-723 & 15.2 & 106 & 0.462 & 53 & 0.116 & 23 & 0.045 & 25 \\
\hline INF 01012 & WUKR 06-417 & 27.0 & 189 & 0.473 & 54 & 0.186 & 36 & 0.047 & 26 \\
\hline INF 01013 & WUKR-846 & - & - & 0.021 & 2 & 0.014 & 3 & 0.013 & 7 \\
\hline INF 01014 & WIG 09-14 & 16.3 & 114 & 0.458 & 53 & 0.270 & 54 & 0.103 & 58 \\
\hline \multirow[t]{2}{*}{ INF 00685} & Abby & 9.8 & 69 & 0.898 & 103 & 0.585 & 117 & 0.197 & 110 \\
\hline & AC Linora & 20.4 & 143 & 0.904 & 104 & 0.548 & 100 & 0.207 & 116 \\
\hline INF 00648 & AC Mc Duff & 9.6 & 67 & 1.213 & 139 & 0.693 & 139 & 0.259 & 145 \\
\hline \multirow[t]{2}{*}{ INF 00683} & Alfonso Inta & 11.1 & 78 & 0.890 & 102 & 0.642 & 128 & 0.110 & 61 \\
\hline & Amon & 15.3 & 107 & 1.43 & 164 & 0.657 & 131 & 0.221 & 123 \\
\hline INF 00540 & Dufferin & 10.8 & 76 & 0.985 & 113 & 0.641 & 128 & 0.223 & 125 \\
\hline INF 00592 & Jenny & 12.6 & 88 & 0.812 & 93 & 0.562 & 112 & 0.227 & 127 \\
\hline INF 00061 & Kotowiecki & 14.1 & 99 & 1.099 & 126 & 0.615 & 123 & 0.194 & 108 \\
\hline \multirow[t]{2}{*}{ INF 00692} & Kreola & 13.3 & 93 & 1.043 & 120 & 0.583 & 117 & 0.202 & 113 \\
\hline & La Estanzuela 17 & 9.6 & 67 & 0.720 & 83 & 0.387 & 77 & 0.183 & 102 \\
\hline INF 00575 & La Estanzuela 117 & 7.9 & 55 & 0.901 & 103 & 0.621 & 124 & 0.130 & 73 \\
\hline INF 00578 & La Prevision & 13.4 & 94 & 0.895 & 103 & 0.678 & 136 & 0.149 & 83 \\
\hline INF 00065 & LCSD 200 & 13.4 & 94 & 0.883 & 101 & 0.553 & 111 & 0.223 & 125 \\
\hline INF 00580 & Lino de Pedre & 11.9 & 83 & 0.877 & 101 & 0.548 & 110 & 0.194 & 108 \\
\hline INF 00843 & Lola & 17.8 & 124 & 1.027 & 118 & 0.666 & 133 & 0.224 & 125 \\
\hline- & Manchwrian & 17 & 119 & 1.043 & 120 & 0.649 & 130 & 0.197 & 110 \\
\hline INF 00273 & Medra & 12.8 & 90 & 1.106 & 127 & 0.812 & 162 & 0.189 & 106 \\
\hline INF 00584 & Maroc & 13.5 & 94 & 0.930 & 107 & 0.557 & 111 & 0.209 & 117 \\
\hline $\begin{array}{l}\text { INF } 00080 \\
\text { INF } 00617\end{array}$ & Noralta & 18.9 & 132 & 0.963 & 110 & 0.610 & 122 & 0.238 & 133 \\
\hline INF 00547 & Norlin & 16.6 & 116 & 1.109 & 127 & 0.651 & 130 & 0.246 & 137 \\
\hline INF 00687 & Olinette & 10.7 & 75 & 0.598 & 69 & 0.334 & 67 & 0.139 & 78 \\
\hline INF 00635 & Opal & 14.1 & 99 & 0.458 & 53 & 0.234 & 47 & 0.098 & 55 \\
\hline INF 00686 & Peak & 11.3 & 79 & 0.834 & 96 & 0.442 & 88 & 0.186 & 104 \\
\hline INF 00290 & Rau & 14 & 98 & 0.939 & 108 & 0.575 & 115 & 0.193 & 108 \\
\hline INF 00096 & Redwood & 12.8 & 90 & 1.330 & 153 & 0.857 & 171 & 0.315 & 176 \\
\hline INF 00689 & Royale & 18.8 & 131 & 0.725 & 83 & 0.429 & 86 & 0.206 & 115 \\
\hline INF 00604 & T-397 & 14.6 & 102 & 0.872 & 100 & 0.540 & 108 & 0.213 & 119 \\
\hline \multirow[t]{3}{*}{ INF 00602} & Tawahar 17 & 17.7 & 124 & 0.951 & 109 & 0.566 & 113 & 0.212 & 118 \\
\hline & Min & 7.9 & 55 & 0,021 & 2 & 0.014 & 3 & 0.013 & 7 \\
\hline & Max & 27 & 189 & 1.43 & 164 & 0.857 & 171 & 0.315 & 176 \\
\hline
\end{tabular}




\section{RESULTS}

Morphological trials were investigated according to the descriptors of characterization and evaluation for International Flax Database (IFDB) [6, 7]. Descriptors state is evaluated in "Descriptor list for flax (Linum usitatissimum L.)" [8].

Plant growth habit for all flax accessions were erect. Plant life cycle of 33 flax accessions was annual. According to the IFDB the total plant length refers to the plant natural height and the technical length is the same that stem length [5]. The total plant length of the flax plants ranged from $51.4 \mathrm{~cm}$ - short (La Estanzuella 117) to $76.5 \mathrm{~cm}$ - medium (WUKR 06-417) (tab. 3). According to the methodology of the International Database, they were usually short (28 accessions), medium short (3) and medium (1) (tab. 3). There were no genotypes of the following total plant length: extremely short, medium long, long and extremely long. The technical length ranged from $34.8 \mathrm{~cm}$ - short (Kreola - linseed) to $61.5 \mathrm{~cm}$ - medium short (WUKR-06-417 landrace). There were no accessions of extremely short, medium, medium long, long and extremely long technical length. The following genotypes were also distinguished in terms of stem length: Medra (60.3 cm - medium short), Maroc (55.4 cm - medium short) and Manchwrian (53.9 - medium short) (tab. 3). The technical length of 28 flax accessions was short. The thickness of the stem in the middle of the technical length of 28 accessions was medium (IFDB) and ranged from 1.57 (Amon - linseed) to $1.99 \mathrm{~mm}$ (Maroc - linseed) (tab. 3). The thickness of the stem in the middle of the technical length was thick for the following genotypes: Lola $-2.03 \mathrm{~mm}$, WIG 09-14 - $2.13 \mathrm{~mm}$, Opal - $2.28 \mathrm{~mm}$ and Alfonso Inta $-2.5 \mathrm{~mm}$. The range of panicle length variation was from $11.2 \mathrm{~cm}$ - short (Abby - linseed) to $22.5 \mathrm{~cm}$ - long (Opal - linseed) (tab. 3). The panicle lenght (like - size) [20] was short (7-21\% of plant natural height) for 6 genotypes, medium (22-34\% of plant natural height) for 25 flax accessions and long (35-48\% of plant natural height) for 1 accession of flax (Opal - linseed). Petal colour of corolla of flax flower was light blue for 1 genotype (LSCD 200), blue for 30 accessions of flax, violet-blue for 1 accession (Olinette), and white for 1 variety Amon (tab. 3 ). The 1000-seed weight was low for 25 genotypes and very low for 8 accessions of flax (tab. 3).

Table 4 presents the valorisation of two vegetation periods. The growing season from sowing to the beginning of flowering was very long for the majority of plants (18 accessions), and from sowing to yellow maturity it was long for the largest number of genotypes (14 accessions). The accessions of flax that stood out in terms of fibre content in stem were WUKR 06-417 (27\%) and AC Linora (20.4\%). The following genotypes achieved the highest total yield: Amon, Redwood, AC Mc Duff Medra and Norlin. The highest straw yield was obtained in the cultivation of the following flax accessions: Redwood, Medra, AC Mc Duff, La Prevision and Lola. Taking into account the fact that most of the valorised flax genotypes are flax of the linseed-type, the seed yield is the most important among agricultural trials presented in table 5. The highest seed yield per plot was obtained after ginning seed bags of the following linseed flax varieties: Redwood, AC Mc Duff, Norlin, Noralta and Jenny.

\section{DISCUSSION}

The Programme for Genetic Resources of Cultivated Crops Protection in Poland is coordinated by the Plant Breeding and Acclimatization Institute (IHAR) [5]. Institute of Natural Fibres and Medicinal Plants (INF\&MP), formerly Institute of Natural Fibres, has been responsible for gathering and evaluation of genetic resources of Linum genus since 1982.

The Plant Breeding and Acclimatization Institute has a long-term storage of genetic resources of cultivated plants, in which local varieties, old breeding lines and varieties are deposited. The advantage of local varieties is that they are adapted to the given habitat conditions. An old varieties and breeding lines also show specific biological features. All the old lines and varieties of $L$. usitatissimum have seeds invaluable for humans and animals, although their yield is worse than that of new varieties. New varieties of flax may have been changed (modified) by breeders, which results in a change of seed quality. The seeds modified by breeders have an altered composition of fatty acids, which is not beneficial for human and livestock health, because we must, like endogenous amino acids, supply the body with fatty acids. The problem of contemporary civilized world is the lack or shortage of $\alpha$-linolenic acid (omega-3) in food and too high intake of linoleic acid (omega-6). This fact and exceeding the recommended by WHO ratio of omega-6/omega-3 (4:1) causes many civilization diseases, mainly in Western Europe. This fact is reported by doctors and scientists $[2,9,10-13]$. Therefore, the widespread cultivation of flax to obtain flax seeds, which contain in 
seed oil from $48.1 \%$ (Liflora) - 59.9\% (Alfonso-Inta) $\alpha$-linolenic acid [12, 3].

The L. usitatissimum species is very sensitive, therefore its morphological, biological and agricultural features depend on the meteorological conditions $[14,15]$. Analysing the results of Opal and Jenny, which was also tested in 2008 and 2009, we see that the IFDB descriptors are sometimes the same and sometimes different. Total plant height for 2008, 2009 and 2010 were as follows for Opal: medium short $(68.3 \mathrm{~cm})$, medium $(80.7 \mathrm{~cm})$ and short $(61.2 \mathrm{~cm})$; for Jenny: medium $(80.2 \mathrm{~cm})$, medium long $(91.8 \mathrm{~cm})$ and short $(64.7 \mathrm{~cm})[16]$. The technical length results in 2008, 2009 and 2010 were as follows for Opal: short $(48.4 \mathrm{~cm})$, medium short $(61 \mathrm{~cm})$, short $(38.7 \mathrm{~cm})$; Jenny: medium $(65.2 \mathrm{~cm})$, medium $(70.3 \mathrm{~cm})$, short $(49.5 \mathrm{~cm})$. Stem thickness does not differ much in consecutive years. Panicle length in 2008, 2009 and 2010 was as follows: Opal: medium $(19.9 \mathrm{~cm})$, medium $(19.7 \mathrm{~cm})$ and long $(22.5 \mathrm{~cm})$; Jenny: short $(15 \mathrm{~cm})$, medium $(21.5 \mathrm{~cm})$ and medium $(15.2 \mathrm{~cm})$. The 1000 seed weight results also differ from 2008 to 2010: Opal: low: $7.10 \mathrm{~g}$ (2008), $6.98 \mathrm{~g}$ (2009), $5.91 \mathrm{~g}$ (2010); Jenny: low: $5.63 \mathrm{~g}$ (2008), $6.22 \mathrm{~g}$ (2009) and $4.73 \mathrm{~g}(2010)$. The weight of 1000 seeds and the number of bags collected from the panicle largely affect the obtained seed yield. Accessions with a high seed yield are recommended for cultivation, for example, for their own needs (for health) in order to ensure the necessary $\alpha$-linolenic unsaturated fatty acid.

\section{CONCLUSION}

Hereafter are the conclusions resulting from the valorisation of 33 flax accessions:

1. The determination of individual morphological, biological and agricultural features of flax helps breeders select starting material for the breeding of new flax varieties.

2. The most useful for cross breeders are genotypes that show high yields or have high values of morphological traits that affect yield.

3. The highest seed yields were obtained from following genotypes: Redwood, AC Mc Duff, Norlin, Noralta and Jenny.

4. Jenny is a line of oilseed flax that could be registered as a new variety.

5. For the Manchwrian linen accession you have to grant the accession number. The Noralta flax accessions has a duplicate - two accession number (INF00080 = INF00617) and two collecting number $(165591=166111)$
6. The following flax accessions should be submitted to IHAR for preparation of samples of these genotypes for long-term storage: AC Linora, Amon, La Estanzuela 117.

7. The two vegetation period studied were short for the following flax accessions: AC Linora, Manchwrian, Noralta and T-397.

8. The height of the tested flax plants was usually short, their technical length was short, the diameter of the stems - medium and the length of the panicles - medium.

9. Flax genotype WUKR-846 (I2010/0031) should be deleted from the flax genetic resources collection and considered as worthless as breeding material.

\section{ACKNOWLEDGEMENT}

These works were financed by the Ministry of Agriculture and Rural Development, which commissioned INF\&MP to implement the following topic: "Collection, protection, evaluation and maintenance in a living state and making available for the needs of the national economy genetic resources of crop plants and their pathogens, in the field of varieties and ecotypes of flax, hemp and protected and rare species of medicinal plants". This topic was an area 1 of the multiannual program called "Plant Improvement for Sustainable AgroEkoSystems, High-Quality Food and Plant Production for NonFood Purposes" and was coordinated by the Plant Breeding and Acclimatization Institute in Radzików. INF\&MP along with IHAR in Radzików implemented the same area of the long-term program, therefore there is no conflict of interest.

Conflict of interest: Authors declare no conflict of interest.

\section{REFERENCES}

1. Oomah DB. Flaxseed as a functional food source. J Sci Food Agr 2001; 81(9):889-894. doi: http:// dx.doi.org/10.1002/jsfa.898

2. Matławska I, Bylka W. Naturalne niezbędne kwasy tłuszczowe w profilaktyce chorób cywilizacyjnych. Herba Pol 2007; 53(2):39 [in Polish].

3. Silska G. Genetic resources of flax (Linum usitatissimum L.) as very rich sources of $\alpha$-linolenic 
acid. Herba Pol 2017; 63(4):26-33. doi: http:// dx.doi.org/10.1515/hepo-2017-0022

4. Janiak MA, Silska G, Penkacik K, Sulewska K, Karamać M, Amarowicz R. Flax seed as a source of antioxidants In: Proceedings of the $34^{\text {nd }}$ Scientific Conference: Oilseed Crops 2018. Poznań, Poland 2018:115-116.

5. Silska G, Bocianowski J. Characterisation and evaluation of morphological trials, biological features and seed yield of 23 flax accessions ( $L i$ num usitatissimum L.) of different geographical origins. Herba Pol 2018; 64(4):1-13. doi: http:// dx.doi.org/10.2478/hepo-2018-0019

6. Pavelek M, Faberova I. Klasifikator (Linum usitatissimum L.). $1^{\text {st }}$ ed. Sumperk 2000 [in Slovakian].

7. Pavelek M. Descriptors for evaluation of flax. In: Workshop summary of the second meeting of the Flax, Brno 1994.

8. Nôžková J. Descriptors for flax (Linum usitatissimum L.). $1^{\text {st }}$ ed. Nitra 2011:1-101.

9. Schneider Z. Polyunsaturated fatty acids in the diet - how much is too much? In: Proceedings of the hemp, flax and other bast fibrous plants - production, technology and ecology - Symposium. Poznań 1998; 1:90-96.

10. Łoźna K, Kita A, Styczyńska M, Biernat J. Skład kwasów tłuszczowych olejów zalecanych w profilaktyce chorób cywilizacyjnych. Probl Hig Epidemiol 2012; 93(4):871-875 [in Polish].
11. Trela A, Silska G, Chyc M, Latowski M, Kruk J, Szymańska R. Tocochromanols and fatty acids composition in flax (Linum usitatissimum L.) accessions. Acta Soc Bot Pol 2019; 88(4):1-12. doi: http://dx.doi.org/10.5586/asbp.3636

12. Silska G. The unique composition of fatty acids of flax, from the Linum usitatissimum L. collection. Biomed J Sci Tech Res 2019; 18(4):1373113736. doi: http://dx.doi.org/10.26717/ BJSTR.2019.18.003178

13. Silska G. Walkowiak M. Comparative analysis of fatty acid composition in 84 accessions of flax ( $L i$ num usitatissimum L.). J Pre-Clin Clin Res 2019; 13(3):118-129. doi: http://dx.doi.org/10.26444/ jpccr/111889

14. Casa R, Russel G, Lo Cascio B, Rossini F. Environmental effects on linseed (Linum usitatissimum L.) yield and growth of flax at different stand densities. Eur J Agron 1999; 11:267-278. doi: http:// dx.doi.org/10.1016/S1161-0301(99)00037-4

15. Kraska P, Andruszczak S, Kwiecińska-Poppe E, Różyło K, Świeca M, Palys E. Chemical composition of seeds of linseed (Linum usitatissimum L.) cultivars depending on the intensity of agricultural technology. J Elementol 2016; 21(2):425-433. doi: http://dx.doi.org/10.5601/ jelem.2014.19.4.814

16. Silska G, Praczyk M. Ocena obiektów kolekcyjnych lnu oleistego (Linum usitatissimum L.). Rośliny Oleiste 2012; 33(1):127-138 [in Polish]. 